\title{
PENINGKATAN MINAT BACA BUKU FIKSI \\ PADA SISWA KELAS IX-D SMPN 3 NGRAMBE MELALUI KONTRAK MEMBACA
}

\author{
SUYATUN \\ SMPN 3 Ngrambe, Ngawi, Jawa Timur \\ e-mail: suyatunulfa@gmail.com
}

\begin{abstract}
ABSTRAK
Pada zaman teknologi seperti sekarang ini, kita dituntut selalu meng-up to date informasi. Sayangnya penyerapan informasi melalui membaca di negara kita masih sangat rendah. Demikian juga minat baca pada siswa SMPN 3 Ngrambe. Pada kenyataannya orang atau anak lebih suka menonton TV atau bermain HP (WA, instagram, dan lain-lain) ketimbang membaca buku/e-book. Rendahnya minat baca siswa SMPN 3 Ngrambe khususnya kelas 9 perlu mendapat perhatian. Salah satu cara meningkatkan minat baca siswa dengan cara membuat kontrak membaca atau sebuah kesepakatan. Kontrak membaca akan memaksa siswa untuk membaca dengan pembatasan waktu, target jumlah buku, dan dituntut membuat laporan. Adapun permasalahan yang dibahas adalah bagaimanakah peningkatan minat baca buku fiksi pada siswa kelas IX-D SMPN 3 Ngrambe melalui kontrak membaca? Apakah melalui kontrak membaca dapat meningkatkan minat baca buku fiksi pada siswa kelas IX-D SMPN 3 Ngrambe? Strategi yang digunakan deskriptif kualitatif. Dengan subjek penelitian siswa kelas IX-D SMP Negeri 3 Ngrambe, Ngawi. Hasil pengamatan pada siklus I menunjukkan $72 \%$ cukup berusaha membaca. Sedangkan pada siklus II mencapai $76 \%$ yang usaha membacanya baik. Dengan ketuntasan $0 \%$ pada siklus I dan 56\% pada siklus II. Dengan demikian, minat baca dalam pembelajaran literasi membaca buku fiksi melalui kontrak membaca pada siswa kelas IX-D SMPN 3 Ngrambe menunjukkan peningkatan yang signifikan.
\end{abstract}

Kata kunci: minat baca, kontrak membaca

\section{PENDAHULUAN}

Pada zaman teknologi seperti sekarang ini, kita dituntut menyerap atau membaca informasi sebanyak-banyaknya. Apabila kita telat menyerap informasi baru maka akan ketinggalan jauh dengan orang-orang yang selalu meng-up to date informasi yang berkembang. Tentunya orang yang yang telat atau tidak mau mencari dan menyerap informasi baru, bukan tidak mungkin akan tergilas roda kehidupan yang berputar kencang.

Sayangnya penyerapan informasi melalui membaca di negara kita masih rendah. Terbukti dari hasil penelitian-penelitian menunjukkan persentase minat baca anak Indonesia sangat memprihatinkan. Contohnya yang termuat dalam POS-Kupang.Com/Kupang 19 September 2019 yang menyatakan bahwa UNESCO menunjukkan data persentase minat baca anak Indonesia berada di angka 0.001 persen. Angka itu berarti, dari 10.000 anak Indonesia, hanya satu anak yang senang membaca. (https://kupang.tribun news.com, akses 10 Januari 2020 pukul 10.45)

Fakta-fakta tersebut sangat memprihatinkan bukan? Padahal persoalan membaca merupakan suatu persoalan yang sangat vital dalam dunia pendidikan. Seperti kata Robert Farr dalam seminar KAGUM, 26 Maret 2016 yang termuat dalam Kompasiana 31 Agustus 2018 menyatakan, "membaca adalah jantungnya pendidikan" (https://www.kompasiana.com, akses 10 Januari 2020 pukul 11.35). Selain itu, minat baca juga menjadi kunci kemajuan suatu bangsa, seperti yang dikatakan Suharmono Kasiyun (2015), "Minat baca menjadi kunci penting bagi kemajuan suatu bangsa, karena penguasaan Iptek hanya dapat diraih dengan minat baca yang tinggi, bukan kegiatan menyimak atau mendengarkan."

Henry Guntur Tarigan juga menyampaikan, "orang yang membaca dengan baik adalah orang yang biasanya berpikir baik; dia memiliki dasar suatu pendapat dan suatu batu ujian bagi pertimbangan. Orang yang setengah buta huruf acapkali ditandai oleh minat-minat 
yang amat terbatas dan ruang lingkup bacaan yang terbatas." (1985: 105) Maka dapat kita katakan bahwa dengan membaca dapat mengukur tingkat kecerdasan, dapat sebagai pondasi bahkan penggerak yang utama atas keberhasilan seseorang dan secara tidak langsung keberhasilan bidang pendidikan akan mengikut.

Untuk itu, minat baca anak perlu mendapat perhatian dan ditingkatkan. Salah satunya melalui pembelajaran bahasa Indonesia. Karena dalam pembelajaran bahasa Indonesia keterampilan yang diajarkan mencakup keterampilan membaca, menulis, berbicara, mendengarkan, dan apresiasi sastra. Pembelajaran dapat diarahkan pada kegiatan-kegiatan yang dapat melatih siswa meningkatkan kemampuan membaca, menulis, berbicara, mendengarkan, dan apresiasi sastra. Dan yang lebih penting lagi penekanan kegiatan untuk meningkatkan minat baca anak.

Selain itu, banyak manfaat dari membaca seperti yang disampaikan Mudini "Manfaat membaca adalah sebagai berikut (1) Menambah kosakata, tatabahasa, dan sintaksis. (2) Mengalami pikiran dan perasaan yang paling dalam. (3) Memicu imajinasi. (4) Memaksa nalar, pengurutan keteraturan dan pemikiran logis untuk dapat mengikuti jalan cerita atau memecahkan suatu misteri." ( 2016: 52) Tentunya orang yang rajin membaca akan memiliki perbendaharaan kata yang lebih banyak, akan mendapatkan pengetahuan, dan secara tidak langsung akan mempengaruhi cara berpikir dan bertindak. Sehingga akan berdampak dalam meraih kesuksesan.

Rendahnya minat baca bangsa kita ini, dapat dibuktikan di lapangan dalam lingkup kecil, misalnya pada siswa SMPN 3 Ngrambe. Terbukti dari tugas membaca buku dalam pembelajaran bahasa Indonesia pada siswa kelas 9 di bulan pertama semester ganjil tahun pelajaran 2019/2020 belum ada satu pun siswa yang meminjam buku di perpustakaan, apalagi membaca buku. Hal tersebut terlihat dari hasil survei guru bahasa Indonesia dengan bertanya di setiap kelas, serentak mengatakan belum.

Kurangnya minat baca anak atau siswa sekarang ini disebabkan oleh banyak faktor. Faktor yang mempengaruhi minat baca anak antara lain faktor lingkungan sekitar, faktor perkembangan teknologi (gadged), faktor diri anak itu sendiri. Demikian juga minat baca siswa SMPN 3 Ngrambe yang masih kurang juga disebabkan oleh lingkungan keluarga yang tidak mendukung untuk membiasakan anak dalam membaca, lingkungan di luar rumah ratarata temannya juga tidak membiasakan budaya baca, anak lebih suka face book, instagram, WA dan lain-lain katimbang membaca. Fakta lain, siswa yang meminjam buku di perpustakaan setiap harinya tidak lebih dari 10 siswa atau $2 \%$ saja dari jumlah siswa 409 siswa.

Salah satu cara meningkatkan minat baca siswa dengan cara membuat kontrak membaca atau sebuah kesepakatan. Dengan membuat kontrak membaca atau sebuah perjanjian yang telah disepakati bersama secara tidak langsung siswa memiliki janji atau utang. Agar perjanjian yang telah disepakati tidak lupa, maka perlu ada kesepakatan tertulis dan sistem. Untuk itu, untuk memudahkan dibuat kontrak membaca.

Kontrak membaca bertujuan untuk memaksa siswa membaca dengan pembatasan waktu dengan target jumlah buku yang harus dibaca. Selain itu siswa dituntut atau dipaksa untuk membuat laporan secara singkat dari isi buku yang dibaca yang harus disetorkan pada guru. Dengan membuat laporan yang disetor dan diberi nilai siswa akan terdorong/termotivasi untuk membaca.

Mengingat banyaknya manfaat dari membaca dalam kehidupan dan rendahnya minat baca anak, maka penulis tergerak melakukan penelitian, yaitu "Peningkatan Minat Baca Buku Fiksi pada Siswa Kelas IX-D SMPN 3 Ngrambe Melalui Kontrak Membaca."

Berdasarkan latar belakang masalah sebagaimana diuraikan di atas, masalah penelitian ini dapat dirumuskan, yaitu bagaimanakah peningkatan minat baca buku fiksi pada siswa kelas IX-D SMPN 3 Ngrambe melalui kontrak membaca? Apakah melalui kontrak membaca dapat meningkatkan minat baca buku fiksi pada siswa kelas IX-D SMPN 3 Ngrambe? Adapun tujuan penelitian ini untuk meningkatkan minat baca dan keterampilan 
membaca buku fiksi pada siswa khususnya siswa kelas IX-D SMPN 3 Ngrambe melalui kontrak membaca.

Hasil dari penelitian ini diharapkan mampu memberikan kontribusi pada pembelajaran bahasa Indonesia, terutama pada pembelajaran literasi sebagai metode pembelajaran alternatif. Selain itu, dapat dipergunakan sebagai referensi untuk penelitian selanjutnya yang berhubungan dengan hal yang senada.

\section{METODE PENELITIAN}

Penelitian ini menggunakan rancangan penelitian tindakan kelas (classroom action research) yang berusaha mengkaji dan merefleksikan secara mendalam beberapa aspek dalam kegiatan pembelajaran. Penelitian tindakan kelas merupakan sebuah kolaboratif dengan pihak lain seperti guru, peserta didik, dan sekolah guna meningkatkan serta menciptakan kinerja yang lebih baik.

Penelitian ini bertujuan untuk mengetahui ada tidaknya minat baca siswa terhadap buku fiksi dengan menerapkan metode kontrak membaca dan tes lisan. Selain itu, penelitian ini juga bertujuan untuk mendiskripsikan penerapan pembelajaran membaca dengan metode kontrak membaca. Dan untuk mengetahui perubahan perilaku siswa dalam membaca buku fiksi.

Penelitian ini direncanakan dua siklus yang disesuaikan dengan alokasi waktu dan materi yang dipilih. Masing-masing siklus terdiri dari empat langkah (Kemmis dan Mc Taggart dalam I Wayan Dasna, 2009: 15) yaitu: a) Perencanaan (planning), yaitu merumuskan masalah, menentukan tujuan dan metode penelitian serta membuat rencana tindakan, b) Aksi atau tindakan (acting), yang dilakukan sebagai upaya perubahan yang dilakukan, c) observasi (observing), dilakukan secara sistematis untuk mengamati hasil atau dampak tindakan terhadap proses belajar mengajar, dan d) Refleksi (reflecting), yaitu mengkaji dan mempertimbangkan hasil atau dampak tindakan yang dilakukan.

Setiap siklus diawali dengan perencanaan dan diakhiri dengan refleksi. Refleksi pada siklus pertama digunakan sebagai dasar untuk merencanakan pelaksanaan siklus kedua. Hasil refleksi siklus kedua digunakan sebagai dasar penyusunan rencana pada siklus ketiga, dan seterusnya. Dan setiap siklus dilaksanakan dalam dua jam pelajaran. Untuk lebih jelasnya, siklus tindakan ini seperti yang tergambar pada bagan di bawah ini.

Subjek penelitian ini adalah siswa kelas IX-D SMPN 3 Ngrambe, Kabupaten Ngawi tahun 2019/2020 yang berjumlah 25 siswa. Dengan materi bahasan literasi membaca buku fiksi. Adapun sumber data dalam penelitian ini meliputi peristiwa dalam proses pembelajaran literasi membaca buku fiksi baik sebelum tindakan maupun setelah tindakan.

Data yang dikumpulkan antara lain, rencana pelaksanaan pembelajaran, foto kegiatan pembelajaran, jurnal membaca buku fiksi, hasil angket, dan hasil pengamatan aktivitas siswa dalam pembelajaran. Pengumpulan data dilakukan dengan teknik dokumentasi, observasi, dan angket.Teknik dokumentasi dilakukan untuk mengetahui minat baca. Teknik observasi digunakan untuk merespon kualitas proses pembelajaran dan minat baca siswa berdasarkan instrumen observasi. Angket digunakan untuk mengetahui minat baca melalui tanggapan siswa terhadap pembelajaran literasi dengan cara kontrak membaca.

Sedangkan teknik analisis data dalam penelitian tindakan kelas ini menggunakan teknik diskriptif kualitatif berupa diskripsi pelaksanaan pembelajaran yang bertitik tolak pada (1) perencanaan, (2) pelaksanaan, (3) pengamatan, (4) refleksi, (5) penilaian.

Indikator keberhasilan proses pembelajaran literasi membaca buku fiksi diketahui dari aktivitas siswa, yaitu melalui konsentrasi/ketekunan siswa dalam membaca, ketepantan waktu dalam mengerjakan tugas/membaca, motivasi siswa selama pembelajaran atau membaca di kelas, sikap siswa selama menyelesaikan tugas membaca, usaha siswa untuk segera menyelesaikan tugas membaca. Indikator peningkatan minat baca dalam penelitian ini diketahui/diukur dari jurnal membaca yang meliputi aspek pelaporan portofolio dan presentasi. 
Maka apabila siswa mendapat skor 15 sama dengan siswa tersebut mendapat nilai maksimal 100.

Penghitungan nilai:

$\mathrm{N}=\frac{\text { Skor waktu+skor portofolio+skor presentasi }}{\text { Skor Maksimal }} \times 100$

Indikator peningkatkan minat baca siswa diketahui melalui hasil observasi terhadap sikap siswa selama proses pembelajaran minimal baik (B). Selain itu, siswa dapat menyelesaikan kontrak membaca buku fiksi dengan mendapat nilai minimal 60 atau dapat menyelesaikan kontrak membaca minimal 1 judul buku fiksi dalam waktu 2 -4 pekan.

Dengan penghitungan nilai, $\mathrm{N}=\underline{\mathrm{Jumlah} \text { skor }} \times 100$

Skor max.

Sedangkan, penganalisisan data hasil penelitian dengan perhitungan statistik sederhana yakni dengan menentukan mean dengan rumus: $X=\frac{\sum X}{\sum N}$. Secara klasikal minat bacanya meningkat apabila siswa yang memperoleh nilai minimal 60 mencapai minimal $70 \%$ dan jumlah siswa yang membaca buku mencapai $70 \%$ dari jumlah siswa di kelas itu.

\section{HASIL DAN PEMBAHASAN}

Penelitian dilakukan dalam dua siklus dan setiap siklusnya ada empat tahap, yaitu perencanaan, pelaksanaan, pengamatan, dan refleksi.

\section{A. Hasil}

A. Siklus I (Kondisi Awal)

Peneliti pada tahap perencanaan menyiapkan bahan ajar, rencana pembelajaran (RPP), menyiapkan model, dan menyiapkan lembar penilaian. Penelitian dilaksanakan pada hari Senin, 29 Juli 2019 di kelas IX-D SMP Negeri 3 Ngrambe, Ngawi, Jawa Timur pada jam pertama tahun pelajaran 2019/2020 dengan jumlah siswa sebanyak 25 anak.

Kegiatan pembelajaran siklus I diawali, guru sekaligus sebagai peneliti membuka pelajaran, mengajak siswa untuk berdoa, mengabsen, mengecek kebersihan kelas, dan guru bertanya tugas membaca buku fiksi yang diberikan pada pertemuan pertama. Selanjutnya, guru sebagai peneliti menjelaskan jenis buku yang harus dibaca, langkah-langkah pembelajaran membaca buku fiksi, format kontrak membaca, memberikan motivasi membaca, dan siswa bersama guru menyepakati kontrak membaca buku fiksi dengan penandatanganan format kontrak membaca yang telah dibuat. Pada akhir pembelajaran guru dan siswa melakukan refleksi terhadap pembelajaran. Guru memberikan tugas rumah (PR) untuk kegiatan membaca buku fiksi dengan batasan waktu satu minggu minimal satu buku. Guru mengumumkan, akan dilakukan penilaian terhadap tugas membaca buku fiksi mulai pertemuan berikutnya. Pada pertemuan ini belum belum ada siswa yang melaksanakan tugas, maka belum bisa dilakukan penilaian.

Indikator peningkatan minat baca dalam pembelajaran literasi membaca buku fiksi pada siklus ini, belum ada satu pun (0\%) siswa yang membaca dan mengumpulkan portofolio atau laporan membaca. Sehingga pada siklus ini belum bisa dilakukan penilaian.

Indikator keberhasilan proses pembelajaran leterasi membaca buku fiksi yang dilihat dari

hasil pengamatan terhadap siswa selama pembelajaran sangat memprihatinkan. Hanya ada dua siswa perempuan yang tekun membaca, mempergunakan waktu dengan baik, termotivasi untuk segera membaca buku fiksi. Sedangkan siswa yang lain terutama anak lakilaki lebih cenderung kurang antusias meminjam buku di perpustakaan dan yang sudah mendapatkan buku juga tidak segera membacanya. Setelah semua siswa meminjam buku diperpustakaan, aktivitas yang dilakukan membaca buku fiksi.

Keberhasilan proses dan minat baca dalam pembelajaran literasi membaca buku fiksi pada siklu I dapat digambarkan melalui grafik berikut ini. 


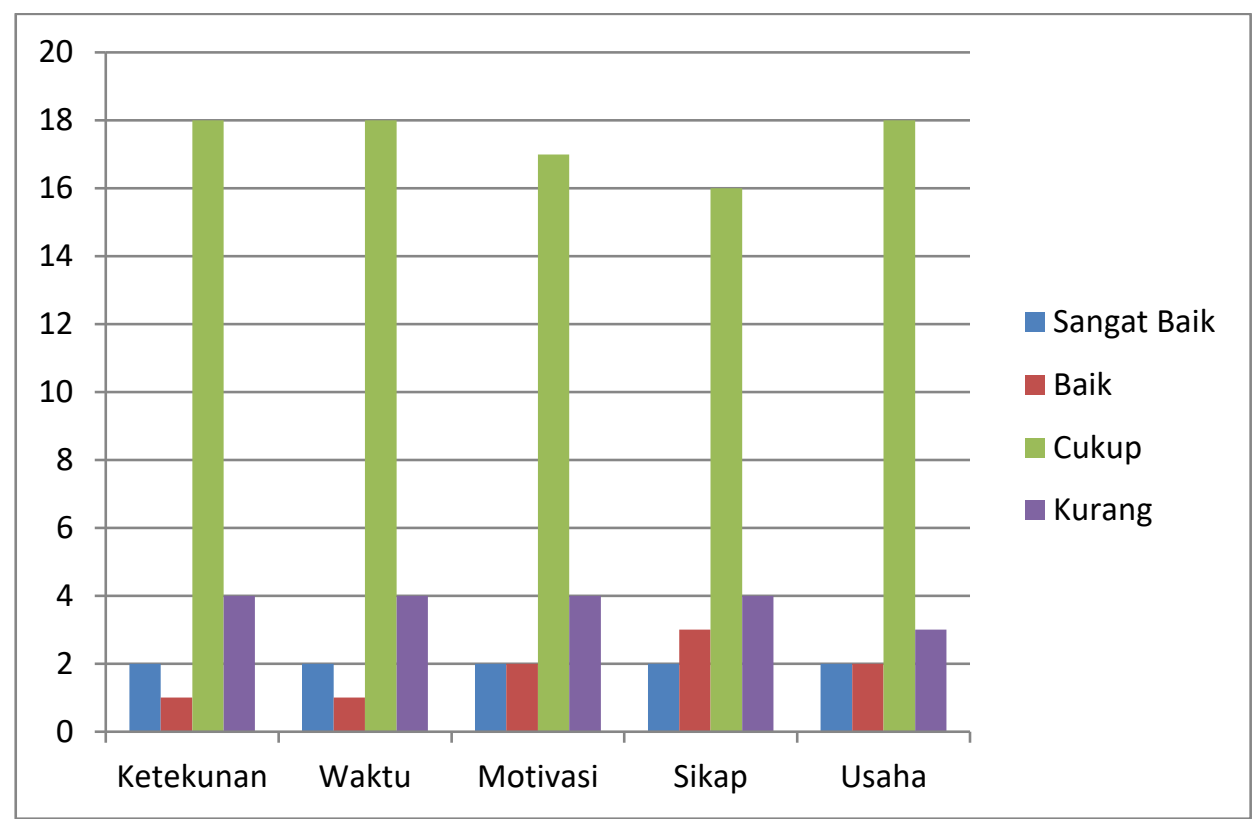

\section{Gambar 1. Keberhasilan Proses Pembelajaran Literasi Membaca Buku Fiksi pada Siklus I}

Grafik di atas menggambarkan siswa kelas IX-D dalam mengikuti pembelajaran literasi membaca buku fiksi ketekunan, pemanfaatan waktu, motivasi siswa dalam membaca, sikap siswa, dan usaha siswa dalam membaca rata-rata cukup. Dari 25 siswa yang tekun, memanfaatkan waktu dengan baik, mempunyai motivasi membaca, sikap dan usaha untuk membaca buku fiksi hanya $2(8 \%)$ siswa. Bahkan masih ada 4 siswa yang ketekunan, pemanfaatan waktu, motivasi dalam membaca, dan sikapnya masih kurang.

Setelah dilakukan refleksi pembelajaran literasi membaca buku fiksi melalui kontrak membaca masih terdapat kelemahan yang perlu mendapat perhatian guru. Kelemahankelemahan itu, yakni (1) Siswa belum mengerjakan tugas sesuai kesepakatan waktu dalam kontrak membaca maka guru harus menentukan batas waktu dan mengingatkan siswa untuk memperhitungkan waktu. (2) Siswa banyak yang humor dan santai, kurang berinisiatif untuk segera meminjam buku di perpustakaan dan kurang termotivasi untuk membaca maka guru perlu menumbuhkan semangat belajar atau memotivasi membaca siswa. (3) Siswa banyak yang belum membuat kotrak membaca maka guru segera mengecek satu persatu kontrak membaca siswa. (4) Siswa belum mengerjakan PR membuat laporan portofolio membaca buku fiksi yang telah dibaca. Maka guru perlu memperhatikan tugas siswa untuk diberi penilaian atau diberi penghargaan agar siswa termotivasi untuk membiasakan membaca. Guna memperbaiki kelemahan -kelemahan tersebut maka perlu dilakukan perbaikan pada siklus II.

B. Siklus II

Hal-hal yang dipersiapkan guru pada suklus kedua adalah menyusun rencana pelaksanaan pembelajaran (RPP) perbaikan dari siklus pertama, menyiapkan skeneraio pembelajaran, menyiapkan blangko pengamatan, menyiapkan blangko penilaian. Adapun tugas membaca buku fiksi sudah dilakukan di luar jam pembelajaran. Maka pada pekan ini guru akan melakukan pengecekan dan penangihan.

Langkah-langkah pembelajaran yang dilakukan guru, yakni melakukan pendahuluan pembelajaran dilanjutkan menginformasikan ke siswa dalam pekan ini selama tiga kali pertemuan akan dilakukan penilaian portofolio laporan kontrak membaca. Selaian itu guru akan melakukan tanya jawab secara lisan berhubungan dengan isi buku, memberikan motivasi untuk selalu membaca serta memberikan penjelasan cara membaca yang baik. Sedangkan siswa mencari unsur-unsur buku fiksi, membuat peta konsep alur cerita, merangkum isi buku. 
Bagi siswa yang sudah selesai dan mengumpulkan fortofolio, satu persatu mempresentasikan secara singkat isi buku fiksi yang dibaca. Dan guru memberikan penilaian presentasi siswa. Portofolio akan dinilai di luar jam pembelajaran.

Tahap berikutnya guru dan siswa melakukan refleksi terhadap pembelajaran yang telah dilakukan. Guru mengingatkan lagi kepada siswa yang belum presentasi agar menyelesaikan tugas membaca buku fiksi dengan catatan pekan ini minimal satu buku sudah dilaporkan.

Indikator keberhasilan proses pembelajaran literasi membaca buku fiksi pada siklus kedua, hampir semua siswa sudah membaca buku fiksi. Hanya 3 siswa yang belum mengumpulkan laporan portofolio dan presentasi. Ketiga anak tersebut sudah membaca satu judul buku namun belum selesai. Ketiga siswa ini belum dapat menyelesaikan tugas karena siswa tersebut tergolong anak yang memerlukan perhatian lebih dari orang tua dan guru. Siswa yang lain ada yang kurang dari dua minggu telah mampu membaca 4 buku, ada 8 siswa yang mampu membaca satu judul buku, ada 9 siswa yang mampu membaca satu judul buku dalam 3 pekan, dan hanya 2 siswa yang membaca satu judul buku selama selama 4 minggu atau satu bulan. Jadi sejumlah 22 siswa sudah mengumpulkan portofolio kontrak membaca dan sudah mempresentasikan. Bahkan 4 siswa telah mampu mengumpulkan laporan portofolio lebih dari satu judul buku.

Hasil análisis penilaian terhadap kemampuan membaca buku fiksi yang diambil dari aspek banyaknya waktu yang digunakan untuk membaca, laporan portofolio siswa, dan hasil presentasi siswa menunjukkan 14 siswa atau 56\% siswa mendapatkan nilai sama atau di atas KKM. Dari 25 siswa yang mendapatkan nilai di bawah KKM 11 siswa atau 44\%.

Pengamatan terhadap konsentrasi/ketekunan siswa dalam membaca dapat dikatakan cukup baik. Karena hampir semua siswa berkonsentrasi menyelesaikan laporan portofolio dan presentasi maka siswa yang ketekunannya kurang hanya anak ABK. Sedang kecepatan siswa dalam membaca masih kurang karena siswa banyak yang belum terbiasa membaca. Motivasi siswa dalam membaca sudah terlihat ada perkembangan karena dengan dilakukan penilaian portofolio kontrak membca dan presentasi, siswa terlihat semangat ke perpustakaan dan membaca. Siswa juga berantusias untuk segera presentasi, terbukti beberapa siswa ingin saling mendahului untuk presentasi. Siswa juga sudah ada usaha untuk menyelesaikan tugas membaca, dengan bukti semua siswa di kelas tersebut sudah meminjam buku di perpustakaan dan membaca. Walaupun waktu untuk mrnyelesaikan satu judul buku memerlukan waktu yang cukup lama. Dari data tersebut dapat dikatakan pembelajaran pembiasaan literasi melalui pembelajaran membaca buku fiksi sudah ada peningkatan.

Indikator keberhasilan proses dan minat baca dalam pembelajaran literasi membaca buku fiksi dapat digambarkan melalui grafik berikut ini. 


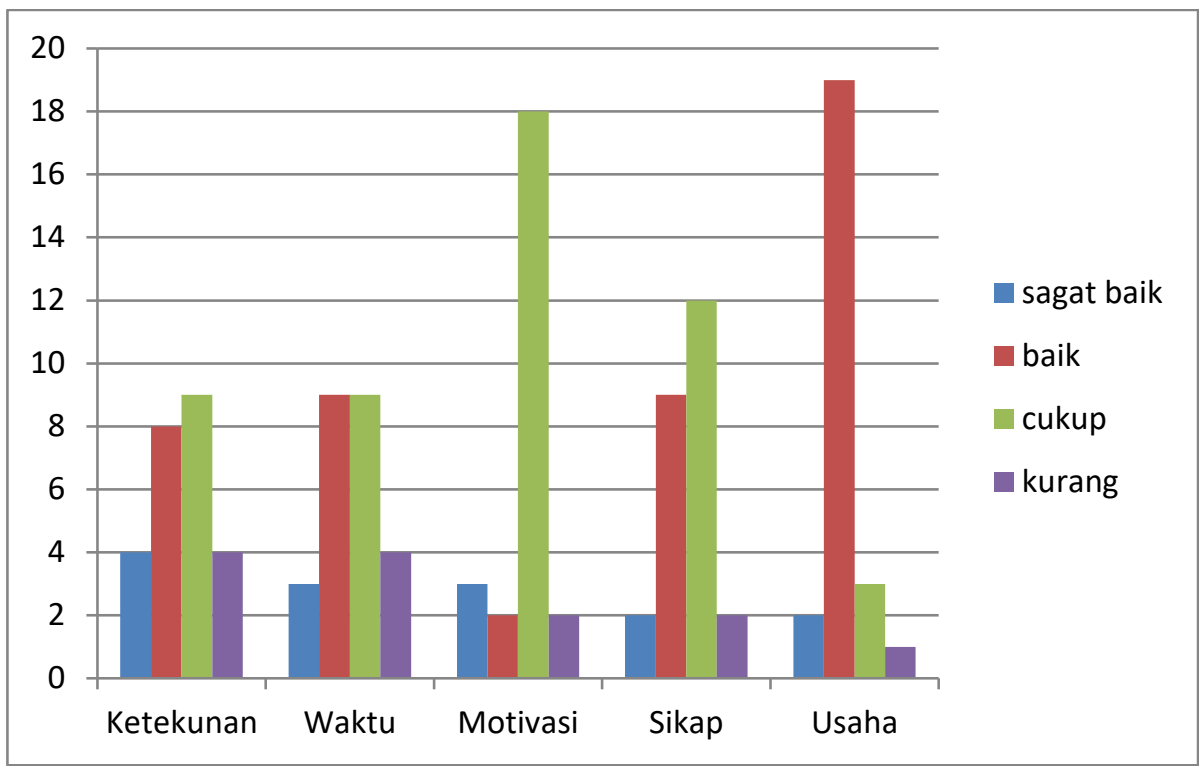

\section{Gambar 2. Keberhasilan Proses Pembelajaran Literasi Membaca Buku Fiksi pada Siklus II}

Grafik di atas menggambarkan siswa kelas IX-D dalam mengikuti pembelajaran literasi membaca buku fiksi dalam ketekunan, pemanfaatan waktu, motivasi siswa, sikap, dan usaha dalam membaca ada peningkatan. Dari 25 siswa yang ketekunan membacanya sangat baik ada 4 siswa, baik 8 (32\%) siswa, dan yang kurang tekun hanya ada 4 siswa. Siswa mampu memanfaatkan waktu sangat baik ada 3 siswa, baik ada 9 (36\%) siswa, dan yang kurang bisa memanfaatkan ada 4 siswa. Siswa yang motivasi membacanya sangat baik ada 3 , baik ada 3, dan cukup baik ada $18(72 \%)$ siswa. Sedangkan siswa yang sikap membacanya sangat baik ada 2, baik ada 9 (36\%), cukup baik ada 12 siswa. Dan ada 19 (76\%) siswa yang ada usaha membaca dengan baik. Dengan demikian proses pembelajaran literasi membaca buku fiksi melalui kontrak membaca dan hasil tugas siswa diberi penghargaan lebih terkondisi.

Refleksi terhadap pembelajaran literasi membaca buku fiksi melalui kontrak membaca dengan hasil tugas siswa diberi penilaian atau penghargaan menjadi lebih baik siswa ada motivasi untuk membaca, siswa juga berusaha untuk membuat laporan portofolio. Karena pada siklus kedua minat baca siswa sudah ada perkembangan baik maka pembelajaran dengan literasi membaca buku fiksi melalui kontrak membaca dengan tugas siswa diberi penilaian dianggap sudah baik maka guru memutuskan untuk tidak dilakukan tindakan siklus beriktnya.

Pada akhir pembelajaran siklus kedua guru memberi angket kepada siswa. Angket dilakukan untuk mengetahui tanggapan siswa setelah mengikuti pembelajaran literasi melalui kontrak membaca. Adapun hasil angket yang diberikan guru kepada siswa menunjukkan 22 siswa (88\%) menjawab memahami. $75 \%$ siswa menjawab tugas membaca dilakukan tidak sesuai kesepakatan, siswa yang menjawab termotivasi 60\% (15 siswa). siswa yang menjawab tidak terbebani sebanyak 18 siswa atau $72 \%$, sedangkan jawaban siswa ingin menyelesaikan kontrak membaca sebanyak $100 \%$.

\section{B. Pembahasan Hasil Penelitian}

Berdasarkan hasil pengamatan, penilaian, wawancara, dan refleksi setiap siklus pada akhir tindakan dapat terlihat dari indikator pencapaian siswa. Hasil pengamatan terhadap proses pembelajaran literasi membaca buku fiksi siswa kelas IX-D pada siklus I dalam ketekunan, pemanfaatan waktu, motivasi membaca, sikap siswa, dan usaha siswa dalam membaca rata-rata cukup. Dari 25 siswa yang tekun, pemanfaatan waktu dengan baik, mempunyai motivasi membaca, sikap, dan berusaha membaca hanya 2 siswa atau $8 \%$. Ratarata $72 \%$ atau 18 siswa dalam ketekunan, waktu, motivasi, sikap, dan usaha hanya cukup. Bahkan ada 4 siswa atau $16 \%$ yang ketekunan, pemanfaatan waktu, motivasi dalam membaca, 
dan sikapnya masih kurang. Pada siklus II dari 25 siswa yang sangat baik tekun membaca ada 4 siswa atau $16 \%$, yang baik 8 siswa atau 32\%, dan yang kurang tekun hanya ada 4 siswa atau $16 \%$. Siswa mampu memanfaatkan waktu sangat baik ada 3 siswa atau $12 \%$, yang baik ada 9 siswa atau $12 \%$, dan yang kurang bisa memanfaatkan ada 4 siswa atau $16 \%$. Siswa yang motivasi membacanya sangat baik ada 3 siswa atau 12\%, yang baik ada 3 siswa atau $12 \%$, dan cukup baik ada 18 siswa atau $72 \%$. Sedangkan siswa yang sikap membacanya sangat baik ada 2 siswa atau 8\%, yang baik ada 9 siswa atau 36\%, cukup baik ada 12 siswa atau $48 \%$. Dan ada 19 siswa atau $76 \%$ yang ada usaha membaca dengan baik. Jadi proses pembelajaran literasi membaca buku fiksi melalui kontrak membaca dengan pemberian nilai pada hasil kontrak membaca, ketekunan, waktu, sikap, dan usaha dalam membaca pada siklus kedua ada peningkatan yang signifikan.

Sedangkan minat baca siswa dalam pembelajaran literasi membaca buku fiksi yang diukur berdasarkan hasil tugas kontrak membaca berupa laporan portofolio dan hasil preasentasi isi buku yang dibaca siswa pada setiap siklus mengalami peningkatan. Peningkatan tersebut setelah guru memberikan penghargaan yang berupa nilai presentasi isi buku dan laporan portofolio.

Keberhasilan peningkatan minat baca dalam pembelajaran literasi dapat dilihat dari hasil penilaian laporan portofolio kontak membaca dan presentasi isi buku fiksi. Pada siklus I siswa yang mengumpulkan tugas masih nol atau belum ada, siswa yang mendapat nilai sama atau di atas KKM masih 0\% (nol siswa), siswa yang nilainya di bawah KKM 100\% (25 siswa), dan rata-rata kelas 0 . Sedangkan perolehan nilai laporan portofolio dan presentasi isi buku fiksi pada siswa IX-D pada siklus II memperoleh nilai di atas KKM sebanyak 56\% (14 siswa), yang mendapat nilai di bawah KKM 44\% (11 siswa), dan rata-rata kelas mencapai 52. Siswa yang memiliki minat baca tinggi sejumlah 14 siswa atau 56\%. Dengan demikian jumlah siswa yang mendapat nilai sama atau di atas KKM mengalami peningkatan $56 \%$ dan nilai rata-rata kelas mengalami peningkatan 52. Meskipun sudah ada peningkatan tetapi secara klasikal belum tuntas.

Penelitian ini berhasil membuktikan, bahwa minat baca anak khususnya dalam pembelajaran literasi membaca buku fiksi melalui kontrak membaca dengan pemberian nilai atau penghargaan dapat ditingkatkan. Hal ini salah satu usaha guru untuk meningkatkan minat baca siswa. Seperti penjelasan Suyatun ( 2019: 59) mengatakan, "Maka siswa perlu diberi motivasi untuk membiasakan diri dalam membaca, diberi penjelasan cara membaca yang benar,.... " Artinya untuk menumbuhkan dan meningkatkan minat baca siswa memerlukan peran guru untuk selalu memberi dorongan atau motivasi.

Selain itu, dengan pemberian nilai atau penghargaan terhadap pembaca juga dapat miningkatkan minat baca, seperti pendapat pada kutipan berikut "Memberikan penghargaan adalah salah satu wujud apresiasi atas tindakan seseorang. Kegiatan memberikan penghargaan kepada pembaca terbaik dapat dilakukan sebagai bagian dari kompetisi." (https://www.ulastopik.com/2019/03/cara-meningkatkan-minat-baca.html, akses Selasa, 29 Juni 2021). Seperti halnya yang disampaikan Harjoprakoso dalam Suharmono Kasiyun (2015) pada Jurnal Pena Indonesia yang menyatakan bahwa untuk meningkatkan minat baca, yaitu dengan mempromosikan membaca sebagai kegiatan keluarga dan sekolah, yang dijadikan sebagai tradisi untuk memberi hadiah buku pada setiap ulang tahun, naik kelas dan lainya, mengajak anak untuk pergu ke toko buku dan memberi kesempatan anak untuk memilih buku sendiri. Dengan itu secara tidak langsung memberi penghargaan atau nilai akan lebih mendorong siswa atau seseorang lebih giat membaca.

Membaca sebuah buku agar segera selesai atau mendapat banyak yang dibaca maka perlu ada pembatasan waktu atau ditarget, seperti penjelasan Agus Humaidi, "Rencana membaca adalah target atau daftar buku apa yang harus ditamatkan untuk dibaca pada minggu atau bulan ini. Saya punya target bahwa setiap bulannya menamatkan sekitar 3-5 buku di luar buku kuliah yang kemudian di resume atau dibuat ringkasannya." (https://dpk.bantenprov.go.id/Layanan/topic/256, akses 29 Juni 2021). Maka jelas sekali 
dengan memberikan motivasi, penghargaan atau nilai dan pembatasan waktu berdasarkan kesepakatan kontrak membaca dapat meningkatkan minat baca siswa.

Tabel 1. Rekapitulasi Minat baca Pembelajaran Literasi Membaca Buku Fiksi

\begin{tabular}{|l|l|c|c|}
\hline No & \multicolumn{1}{|c|}{ Uraian } & $\begin{array}{c}\text { Hasil } \\
\text { Siklus I }\end{array}$ & $\begin{array}{c}\text { Hasil } \\
\text { Siklus II }\end{array}$ \\
\hline 1. & $\begin{array}{l}\text { Jumlah siswa yang } \\
\text { mengerjakan tugas }\end{array}$ & 25 & 25 \\
\hline 2. & Nilai rata-rata & 0 & 52 \\
\hline 3. & $\begin{array}{l}\text { Jumlah siswa yang tuntas } \\
\text { belajar }\end{array}$ & 0 & 14 \\
\hline 4. & Persentase ketuntasan belajar & $0 \%$ & $56 \%$ \\
\hline
\end{tabular}

\section{KESIMPULAN}

Berdasarkan hasil implementasi kontrak membaca dalam pembelajaran literasi membaca buku fiksi dengan pemberian penilaian terhadap laporan portofolio dan presentasi isi buku yang dipaparkan pada hasil penelitian siklus I dan siklus II dapat disimpulkan bahwa peningkatan minat baca siswa dalam pembelajaran literasi membaca buku fiksi melalui kontrak membaca dengan pemberian penilaian terhadap laporan portofolio kontrak membaca dan presentasi isi buku pada siswa kelas IX-D SMPN 3 Ngrambe menunjukkan peningkatan yang signifikan yang pada awalnya nilai atau minat baca $0 \%$ menjadi 56\%. Dan dapat meningkatkan minat baca siswa kelas IX-D SMPN 3 Ngrambe.

\section{DAFTAR PUSTAKA}

Ardiana, Leo Indra. (Eds.). 2002. Pelatihan Terintegrasi Berbasis kompetensi Guru Mata Pelajaran Bahasa Indonesia: Membaca. Jakarta: Depdiknas.

Depatemen Pendidikan Nasional. 2000. Kamus Besar Bahasa Indonesia. Balai Pustaka: Jakarta.

Humaidi, Agus. Buku dan Lunturnya Minat Baca. https://dpk.bantenprov.go.id/Layanan/topic/256, akses 29 Juni 2021.

https://kupang.tribun news.com, akses 10 Januari 2020 pukul 10.45 .

https://www.kompasiana.com, akses 10 Januari 2020 pukul 11.35.

Kasiyun, Harmono. 2015. Upaya Meningkatkan Minat Baca sebagai Sarana untuk Mencerdaskan Bangsa. Jurnal Pena Indonesia (JPI): Jurnal Bahasa Indonesia, Sastra, dan Pengajarannya. Vol.1, Nomor 1.

Mudini. 2016. Mata Pelajaran Bahasa Indonesia SMP/SLB Profesional: Ragam.

Keterampilan Bahasa; Pedagogik: Teori Belajar. Kemendikbud. Modul Guru Pembelajar.

Suyatun. 2019. Peningkatan Kemampuan Membaca Ekstensif dengan Teknik POINT pada Kelas IXC SMPN 3 Ngrambe. Jurnal Pendidikan Matematic Progresif. Volume 4, Nomor 7:59.

Tarigan, Henri Guntur. 1985. Membaca sebagai suatu Keterampilan Berbahasa. Bandung: Angkasa.

12 Cara Meningkatkan Minat Baca Masyarakat Yang Efektif. https://www.ulastopik.com/2019/03/cara-meningkatkan-minat-baca.html, akses Selasa 29, Juni 2021 